\title{
Fat Hypertrophy as a Complication of Fat Transfer for Hemifacial Atrophy - A Case Study
}

Jeon $\mathrm{FHK}^{1}$, Varghese $\mathrm{J}^{2}$, Griffin $\mathrm{M}^{1,2}$, Mosahebi $\mathrm{A}^{1,2}$, Butler $\mathrm{PEM}^{1,2}$, Withey $\mathrm{S}^{2}$, Henderson $\mathrm{H}^{3}$

${ }^{1}$ Division of Surgery and Interventional Science, University College London, ${ }^{2}$ Department of Plastic and Reconstructive Surgery, Royal Free Hospital, London, ${ }^{3}$ Department of Ophthalmology, Royal Free Hospital, London

\begin{abstract}
Fat hypertrophy is a less commonly known complication of autologous fat transfer. We present a 32-year-old female with left hemifacial atrophy associated with systemic sclerosis, who was treated with seven fat transfer procedures to correct the facial asymmetry. A total of $236.5 \mathrm{~mL}$ of fat was injected to the hemiface over a four-year period to achieve good symmetry. A progressively enlarging, painless, soft mass over the left parotid region was noted at three months after the final fat transfer procedure. MRI showed a markedly enlarged bulk of subcutaneous fat over the left cheek with no evidence of necrosis, oedema or pathological enhancement. Concurrent weight gain was noted secondary to additional nutritional input. $115 \mathrm{~mL}$ fat was subsequently removed by liposuction as a result of the patient's aesthetic, symptomatic and functional concerns.
\end{abstract}

\section{$1 \quad$ Background}

Hemifacial atrophy, also known as Parry-Romberg syndrome and Romberg disease, is a rare disorder of unknown aetiology characterized by progressive atrophy involving the skin, subcutaneous tissue, fat, muscle and osteocartilaginous structures of the hemiface. Management options include dermal fillers, fat grafts, dermal-fat grafts, omental free flaps, pedicle flaps, or microvascular free flaps depending on the severity and extent of soft tissue destruction ${ }^{1}$. Autologous fat has many characteristics as the ideal filler for facial soft-tissue defects. Benefits include ease of availability and harvest, minimal donor-site morbidity and aesthetic benefits of improved skin quality, natural contour and facial expression. Complications include unpredictable reabsorption rates leading to multiple procedures to achieve the desired outcome. Less commonly known is the capacity of transplanted adipose tissue to undergo hypertrophy, which can require surgical intervention.

\section{Case Presentation}

A 32-year-old woman presented in September 2009 with left-sided hemifacial atrophy (Figure 1a-1c). Past medical history included a diagnosis of limited systemic sclerosis with Raynaud's and morphea. The hemifacial atrophy was associated with left-sided eye ptosis, enophthalmos, visual loss, left sensorineural hearing loss, central nervous system involvement and gingival atrophy. To treat the asymmetry and symptoms from soft tissue atrophy, fat was transferred using the Coleman technique. Lipoaspirate was harvested from bilateral thighs using a $15 \mathrm{~cm}$ by $3 \mathrm{~mm}$ cannula connected to a $10 \mathrm{~mL}$ syringe and centrifuged at 3000 revolutions per minute, for a total of 3 minutes. Free oil and blood in the proximal portion of the lipoaspirate was discarded and the remaining portion 
consisting of adipose tissue was injected using a $1 \mathrm{ml}$ syringe connected to a blunt cannula. A total of $236.5 \mathrm{~mL}$ of fat was transferred into the left hemiface including the cheek, naso-labial fold, chin, upper and lower lips, nasal ala, temple, left upper and lower eyelid, inner canthus, infra-orbital and retro-orbital area, via small skin incisions, in seven procedures over a four-year period. An average of $33.8 \mathrm{~mL}$ fat was transferred per procedure, ranging five to twelve months between each procedure. Table 1 describes each procedure in detail, as documented in the operation notes.

In Februrary 2014, three months follow-up after the final procedure, a progressively enlarging, painless mass over the left parotid region was observed. On examination a generalised non-pitting soft tissue swelling of the left hemiface from zygoma to jaw line was found. No localised mass, lymphadenopathy, or evidence of vascular occlusion was reported. A subsequent MRI confirmed that the swelling of the cheek consisted of a markedly enlarged bulk of subcutaneous fat, without evidence of necrosis or oedema, or any pathological enhancement following gadolinium (Figure 2a-2b). It was noted that the patient had received a recent percutaneous endoscopic gastro-jejunostomy for gastroparesis resulting in improved nutritional input. Body mass index had increased from 15.2 in June 2013 to 23.3 over a period of 18 months as a result. Figures 3-6(a-c) show post-operative photographs throughout the course of treatment.

\section{$3 \quad$ Treatment}

The patient was monitored as an outpatient over a year but due to increasing heaviness and discomfort, $115 \mathrm{~mL}$ fat was subsequently removed by liposuction in 2015 over two sessions to achieve good symmetry (Figures 7a-7c). Histology specimen showed multiple fragments of lobulated mature adipose tissue with no evidence of lymphatic tissue, dysplasia or malignancy. The patient remained stable for a over a year after liposuction, however due to recurrent problems with gastroparesis secondary to systemic sclerosis, the patient's body mass index gradually dropped down to 15.6 with consequent wasting of soft tissues in the left hemiface.

\section{Discussion}

Autologous fat grafting is a well-established plastic and aesthetic surgical procedure that can be used to address soft tissue defects, that is safe, repeatable and has the advantage of a natural aesthetic outcome. It has also been implicated to have regenerative properties. Despite these favourable characteristics, a major challenge is the variable resorption rate of the injected fat, which remains unpredictable, and patients often undergo multiple procedures to achieve the desired outcome ${ }^{2}$. Optimizing methods of harvesting, processing and injection of fat has been suggested to have impact on fat graft survival ${ }^{3}$, however at present many surgeons choose to overcorrect in order to compensate for the resorption rates.

A rare and more infrequently mentioned complication of autologous fat grafting is derived from the unique capacity of adipose tissue to change dimensions by hypertrophy or hyperplasia as shown in our case report. Similar findings of increased fat bulk have 
been described in the literature following fat grafting procedures to the face. Taupin et al. ${ }^{4}$ who performed lipofilling in a 13-year-old for hemifacial atrophy as with our patient reported a disharmonious increase in the grafted hemiface after a period of 5 years within which the patient had gained $10 \mathrm{~kg}$ in weight secondary to oral contraception and lifestyle changes. Despite a consequent loss of $5 \mathrm{~kg}$ there was little discernible change in the graft bulk, and biopsies from the grafted site showed adipocytes that appeared more concentrated and hypertrophied when compared with adipocytes from the non-grafted hemiface. Hunstad et al. ${ }^{5}$ also treated a 9-year-old patient with hemifacial atrophy with fat grafting. Additional fat grafting was considered, however the patient underwent a significant growth spurt with weight gain with concomitant fullness of the graft site that was easily visible and uncomfortable. Two sessions of liposuction was performed, and histologic analysis of the specimen showed healthy adipose tissue. Miller et al. ${ }^{6}$ performed fat grafting to depressed forehead scars in a 19 year-old female patient and 10 years postoperatively she presented with a recent enlargement of the grafted area, and also reported 15-pound increase in weight in the previous few months. Fat was removed by a combination of liposuction and direct excision. Duhoux et al. ${ }^{7}$ performed fat grafting to the lower lid and upper cheek following tumour excision in a 47 year-old female patient. The patient developed fullness of the graft with concurrent weight gain of $15 \mathrm{~kg}$, which caused a progressive and disabling diplopia, requiring the patient to wear prism glasses for all daily activities. A total of $10 \mathrm{~mL}$ fat was excised and histopathology showed mature adipose tissue.

Reports of fat hypertrophy were not limited to the face but manifested in fat transfer procedures for various indications. Recipient sites included the thigh, pharyngeal wall, dural opening and penile sheath ${ }^{8-11}$. Fat hypertrophy was also implicated in relation to a rectus abdomens deep inferior epigastric perforator flap for pharyngeal reconstruction, which manifested as a painless enlarging neck mass ${ }^{12}$. Age of receiving fat transfer ranged from 8 to 73 years, with time to hypertrophy ranging from 3 months to 10 years. Management consisted of liposuction or fat de-bulking procedures, as conservative management with weight loss was ineffective and delayed definitive treatment. Volume of fat removed ranged from $10 \mathrm{~mL}$ to $250 \mathrm{~mL}$, and repeated procedures were required in some cases due to recurrence ${ }^{9,13}$. Most cases were attributed to concurrent weight gain or in conjunction with a growth spurt. Table 2 summarises the findings.

Consequences of increased graft bulk were dependent on the recipient site. Presenting complaints included obstructive sleep apnoea after pharyngeal wall fat grafting for velopharyngeal incompetence ${ }^{9}$, inability to have sexual intercourse due to reconstruction of the cutaneous penile sheath ${ }^{11}$, and an enlarging mass on follow-up imaging following reconstruction after tumour excision which had to be differentiated from tumour recurrence ${ }^{10,12}$. There was significant psychosocial burden as a consequence of the fat hypertrophy, as was reported in our patient. Liposuction of the graft tissue was complicated in the case of penile sheath reconstruction where there was necrosis of the cutaneous tissue, which required further skin grafting with artificial dermis ${ }^{11}$.

Adipose tissue is a complex organ, which plays a major role in energy and nutrient homeostasis and has a unique capacity to change its dimensions to a significant degree, 
and it has been suggested that there are depot-specific differences in adipocyte physiology ${ }^{14}$. In response to over-nutrition there is an increase in adipocyte cell size (hypertrophy) or recruitment of new adipocytes (hyperplasia). Studies have suggested that adipose depots first expand by hypertrophy until a threshold is reached from when hyperplasia occurs ${ }^{15}$. Other studies determine that processes differ depending on depot location ${ }^{16}$ or that adipocyte number becomes fixed at childhood or early adulthood and that hypertrophy is the main process thereafter ${ }^{17}$. Two theories exist regarding the survival of transplanted fat cells. The host replacement theory suggests that all transplanted fat cells fail to survive and are engulfed by host histiocytes, which become new adipose cells. The cell survival theory suggests that transferred fat cells retain their original storage potential with rapid changes in weight gain or lipogenesis cycle ${ }^{18}$. The findings of fat hypertrophy in conjunction with overall weight gain is more compatible with the latter theory, where the depot-specific response to changes in nutrient intake through fat hypertrophy or hyperplasia is retained regardless of location of transfer. Therefore changes in the lower-limb body fat in our patient as a response to improved nutrition, had direct effect on the fat harvested from the thighs and transferred to the hemiface. When faced with the choice of harvesting from different fat depots, it may benefit the surgeon to understand the pattern of weight gain specific to the individual patient, and depending on the recipient site and end goal of the fat transfer procedure, this knowledge may serve to guide appropriate depot choice. Informing the patient of this tendency would aid in faster recognition and relevant investigation.

In our patient the fat hypertrophy was clearly prominent in the cheek despite fat being transferred to multiple sites in the hemiface, suggesting that despite the identical fat harvest depot location, the recipient location plays a part in fat retention and consequent hypertrophy in the case of our patient. A study looking at fat retention according to sitespecific facial compartments have identified the cheek unit as an independently positive predictor of fat retention, whereas the forehead unit was independently negative ${ }^{19}$. The lips, glabella and temporal regions were also noted to yield poor fat retention compared to the malar and cheek regions ${ }^{20-21}$, suggesting that the areas subjected to movement is inversely correlated to fat retention. To counteract this, Kanchwala et al. ${ }^{21}$ injected botox into the glabella a week prior to fat injection and found a drastic improvement in results.

\section{Conclusion}

Fat transfer is becoming increasingly used as the treatment of choice for soft tissue augmentation. Fat hypertrophy of the transplanted fat graft is a less widely recognised complication of this procedure. Our case study demonstrates that surgeons choosing this treatment modality should be aware of this complication to facilitate early recognition, particularly in functional areas and for discernment between potential tumour recurrence, and for appropriate intervention, which ultimately requires liposuction or direct excision. Patients should be made aware of this complication and that management may require more than one procedure due to recurrence. Alternatively, maintaining a lipid-rich diet may prove effective to retain graft bulk and prevent the post-operative resorption of transplanted fat. 


\section{Disclosure}

The authors declare no conflict of interest.

\section{$7 \quad$ References}

${ }^{1}$ Rodby KA, Kaptein YE, Roring J, Jacobs RJ, Kang V, Quinn KP, et al. Evaluating Autologous Lipofilling for Parry-Romberg Syndrome-Associated Defects: A Systematic Literature Review and Case Report. Cleft Palate Craniofac J 2016;53(3):339-350.

${ }^{2}$ Kaufman MR, Bradley JP, Dickinson B, Heller JB, Wasson K, O’Hara C, et al. Autologous Fat Transfer National Consensus Survey: Trends in Techniques for Harvest, Preparation, and Application, and Perception of Short- and Long-Term Results. Plast Reconstr Surg 2007;119(1):323-331.

${ }^{3}$ Coleman SR. Structural Fat Grafting: More Than a Permanent Filler. Plast Reconstr Surg 2006;118(3Suppl):108S-120S

${ }^{4}$ Taupin A, Labbé D, Nicolas J, Debout C, Benateau H. Lipomodelage et prise de poids. À propos d'un cas et revue de la littérature. Ann Chir Plast Esth 2010;55(3):238-242.

${ }^{5}$ Hunstad JP, Shifrin DA, Kortesis BG. Successful Treatment of Parry-Romberg Syndrome With Autologous Fat Grafting. Ann Plast Surg 2011;67(4):423-425.

${ }^{6}$ Miller JJ, Popp JC. Fat Hypertrophy After Autologous Fat Transfer. Ophthalmic Plast Reconstr Surg 2002;18(3):228-231.

${ }^{7}$ Duhoux A, Chennoufi M, Lantieri L, Hivelin M. Complications of fat grafts growth after weight gain: Report of a severe diplopia. J Plast Reconstr Aesthet Surg 2013;66(7):987990.

${ }^{8}$ Latoni JD, Marshall DM, Wolfe AS. Overgrowth of Fat Autotransplanted for Correction of Localized Steroid-Induced Atrophy. Plast Reconstr Surg 2000;106(7):1566-1569.

${ }^{9}$ Teixeira RP, Reid JA, Greensmith A. Fatty Hypertrophy Cause Obstructive Sleep Apnea after Fat Injection for Velopharyngeal Incompetence. Cleft Palate Craniofac J 2011;48(4):473-477.

${ }^{10}$ Anis K, Sossa D, Sossa D, Castillo M. Intrasellar Fat Graft Gains Weight with the Patient: Imaging Features. Neuroradiol J 2013;26(3):301-303. 
${ }^{11}$ Moullot P, Nguyen P-S, Philandrianos C, Casanova D. Hypertrophie de greffon adipocytaire et lipopénosculpture : gestion d'une complication rare. Ann Chir Plast Esth 2014;59(5):355-359.

${ }^{12}$ Roarke MC, Nguyen BD. Fat Hypertrophy in a Pharyngeal Reconstruction Flap Presenting as an Enlarging Neck Mass: Demonstration of Benign Changes With PET/CT. Clin Nucl Med 2006;31(1):48-49.

${ }^{13}$ Rousvoal A, Délia G, Casoli V, Martin D. Hypertrophie du tissu adipeux après Lipostructure ${ }^{\circledR}$ chez un sujet séropositif traité par antirétroviraux. Cas clinique et revue de littérature. Ann Chir Plast Esth 2009;54(4):384.

${ }^{14}$ Rosen ED, Spiegelman BM. What We Talk About When We Talk About Fat. Cell 2014;156(1-2):20-44.

${ }^{15}$ Krotkiewski M, Bjorntorp P, Sjostrom L, Smith U. Impact of obesity on metabolism in men and women. Importance of regional adipose tissue distribution. J Clin Invest 1983;72(3):1150-1162.

${ }^{16}$ Tchoukalova YD, Votruba SB, Tchkonia T, Giorgadze N, Kirkland JL, Jensen MD. Regional differences in cellular mechanisms of adipose tissue gain with overfeeding. Proc Nat Acad Sci U S A 2010;107(42):18226-18231.

${ }^{17}$ Spalding KL, Arner E, Westermark PO, Bernard S, Buchholz BA, Bergmann O, et al. Dynamics of fat cell turnover in humans. Nature 2008;453(7196):783-787.

${ }^{18}$ Peer LA. Cell Survival Theory Versus Replacement Theory. Plast Reconstr Surg 1955;16(3):161-168.

${ }^{19}$ Denadai R, Raposo-Amaral CA, Pinho AS, Lameiro TM, Buzzo CL, Raposo-Amaral CE. Predictors of Autologous Free Fat Graft Retention in the Management of Craniofacial Contour Deformities. Plast Reconstr Surg 2017;140(1):50e-61e.

${ }^{20}$ Mojallal A, Shipkov C, Braye F, Breton P, Foyatier JL. Influence of the recipient site on the outcomes of fat graft- ing in facial reconstructive surgery. Plast Reconstr Surg 2009; 124:471-483.

${ }^{21}$ Kanchwala SK, Bucky LP. Facial fat grafting: The search for predictable results. Facial Plast Surg 2003;19:137-146. 


\section{Figure Legends}

Figures 1a-1c: Female patient aged 32 presenting with hemifacial atrophy, pre-operative

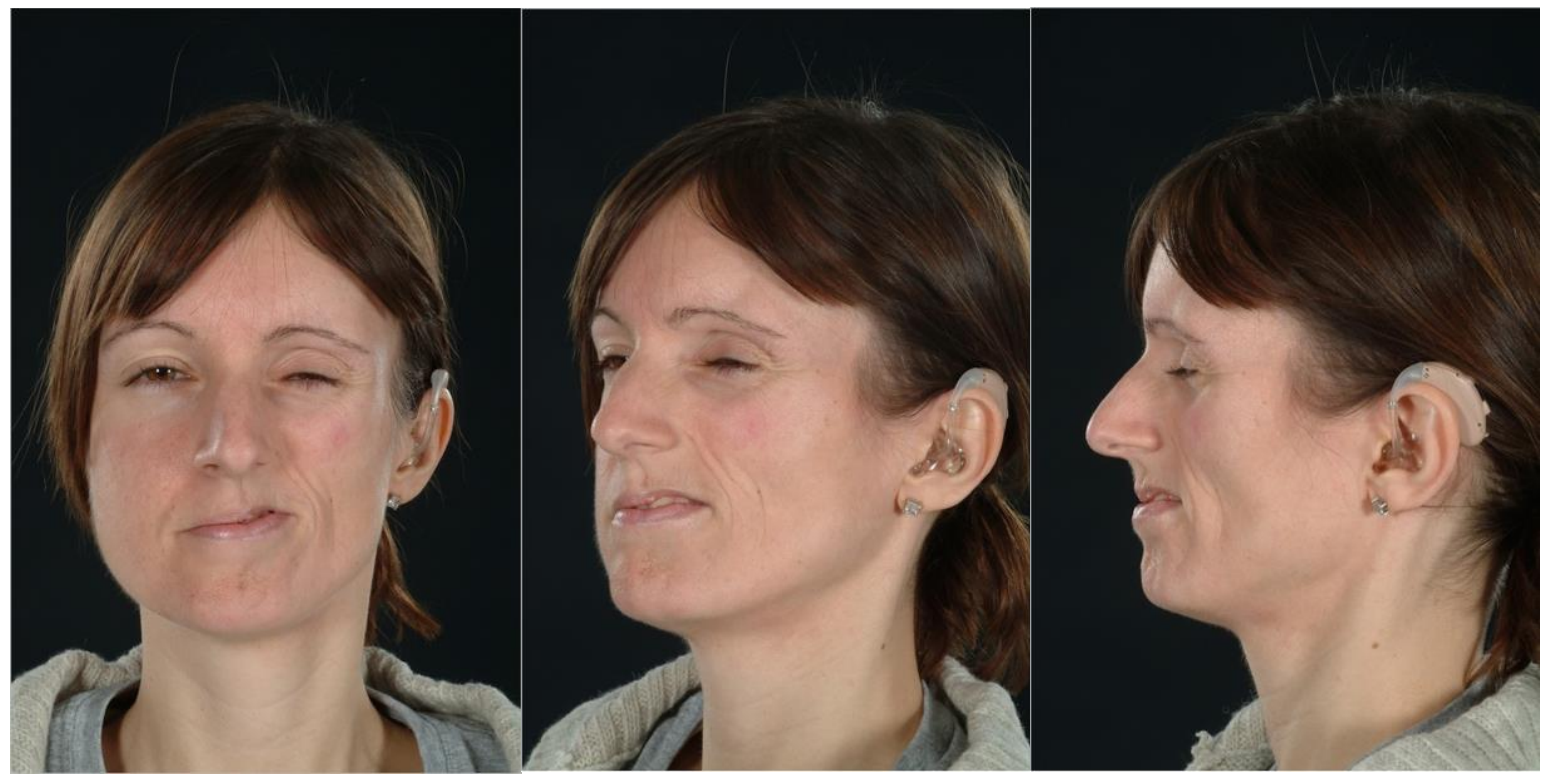

Figures 2a-2b: Magnetic resonance imaging of head showing left-sided fat hypertrophy, 1 months post-operative $7^{\text {th }}$ fat transfer
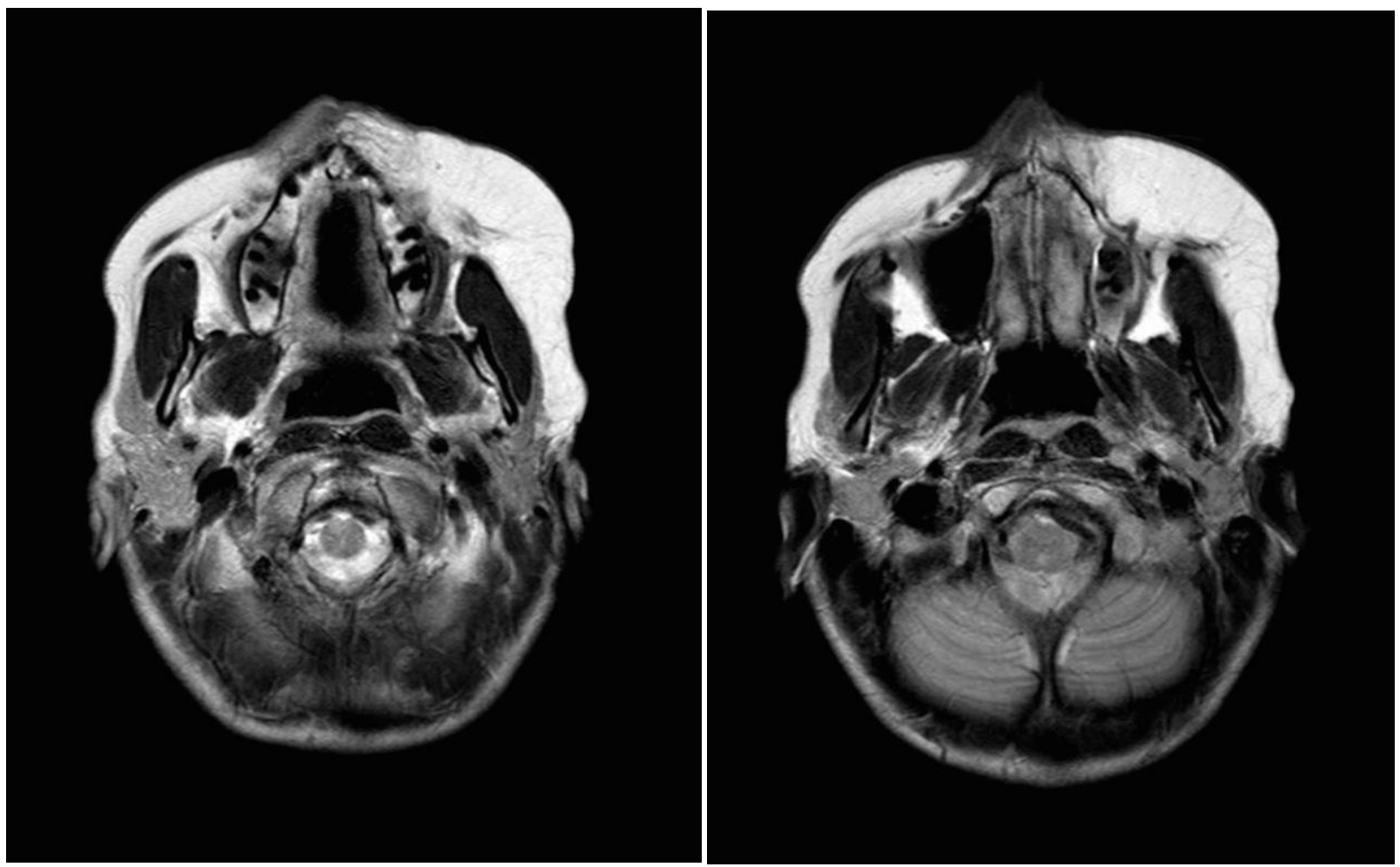
Figures 3a-3c: Female patient aged 35, 2 months post-operative $4^{\text {th }}$ fat transfer

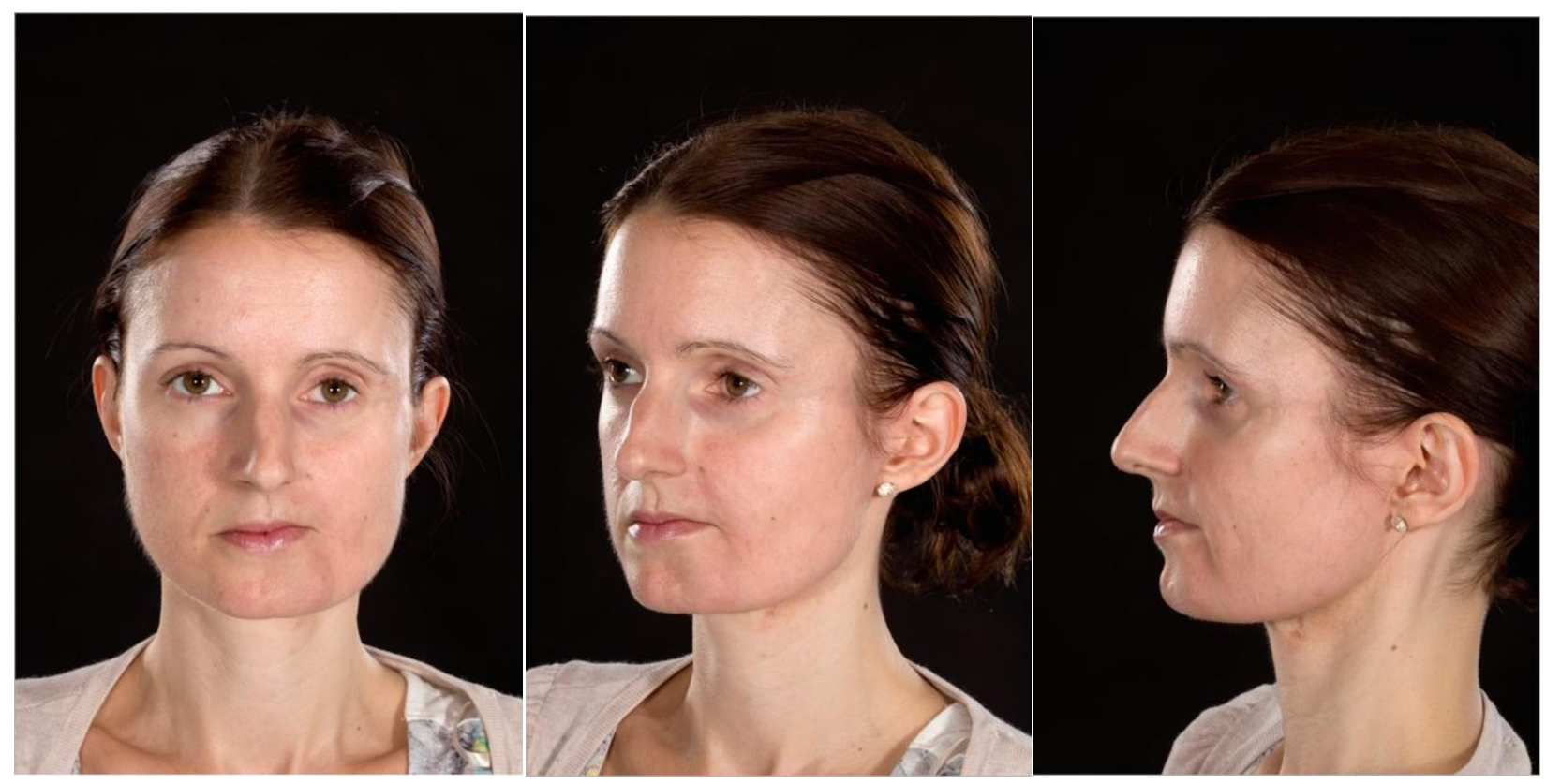

Figures $4 \mathrm{a}-4 \mathrm{c}$ : Female patient aged 37,6 months post-operative $6^{\text {th }}$ fat transfer

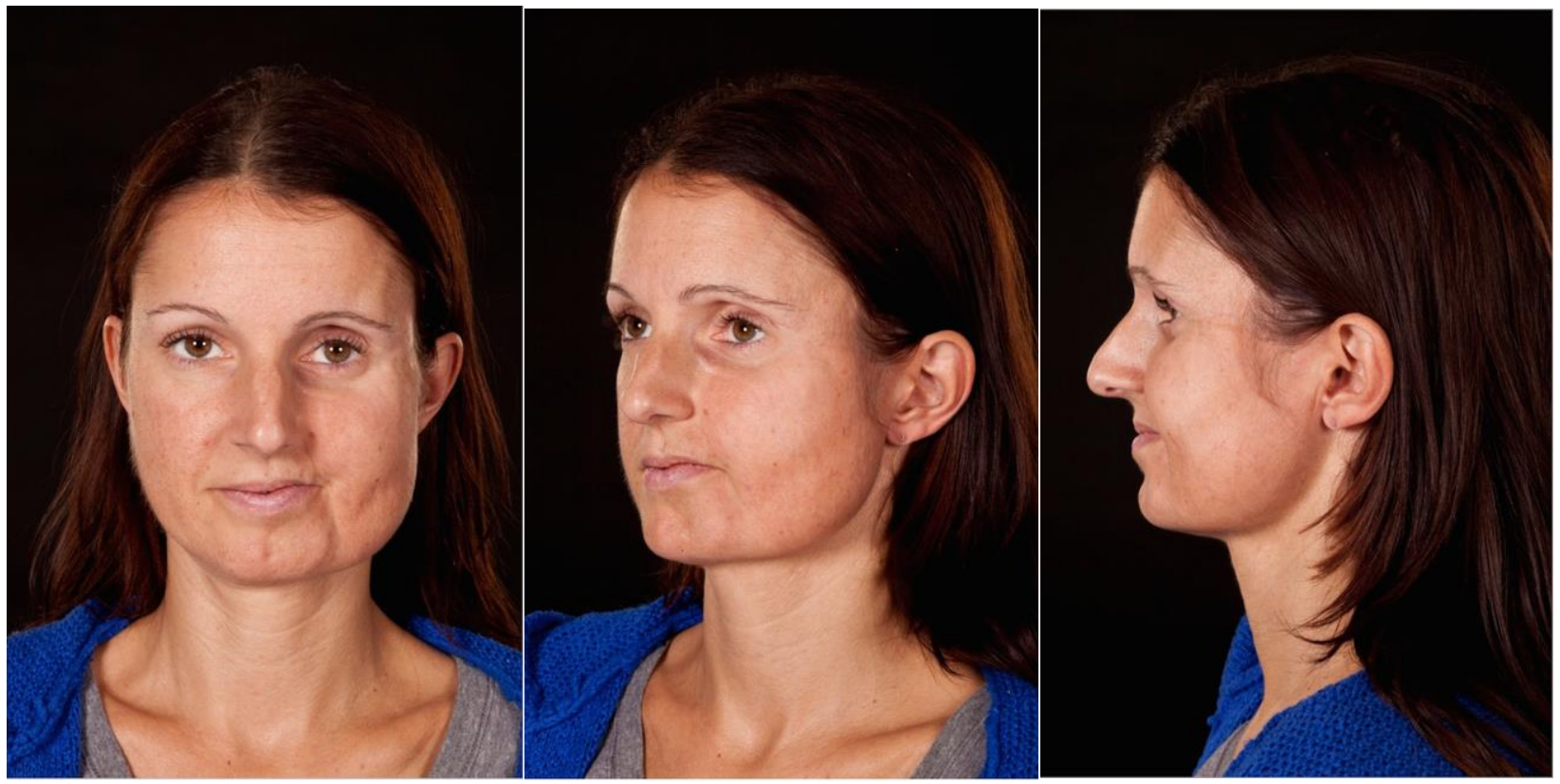


Figures 5a-5c: Female patient aged 37, 6 months post-operative $7^{\text {th }}$ fat transfer

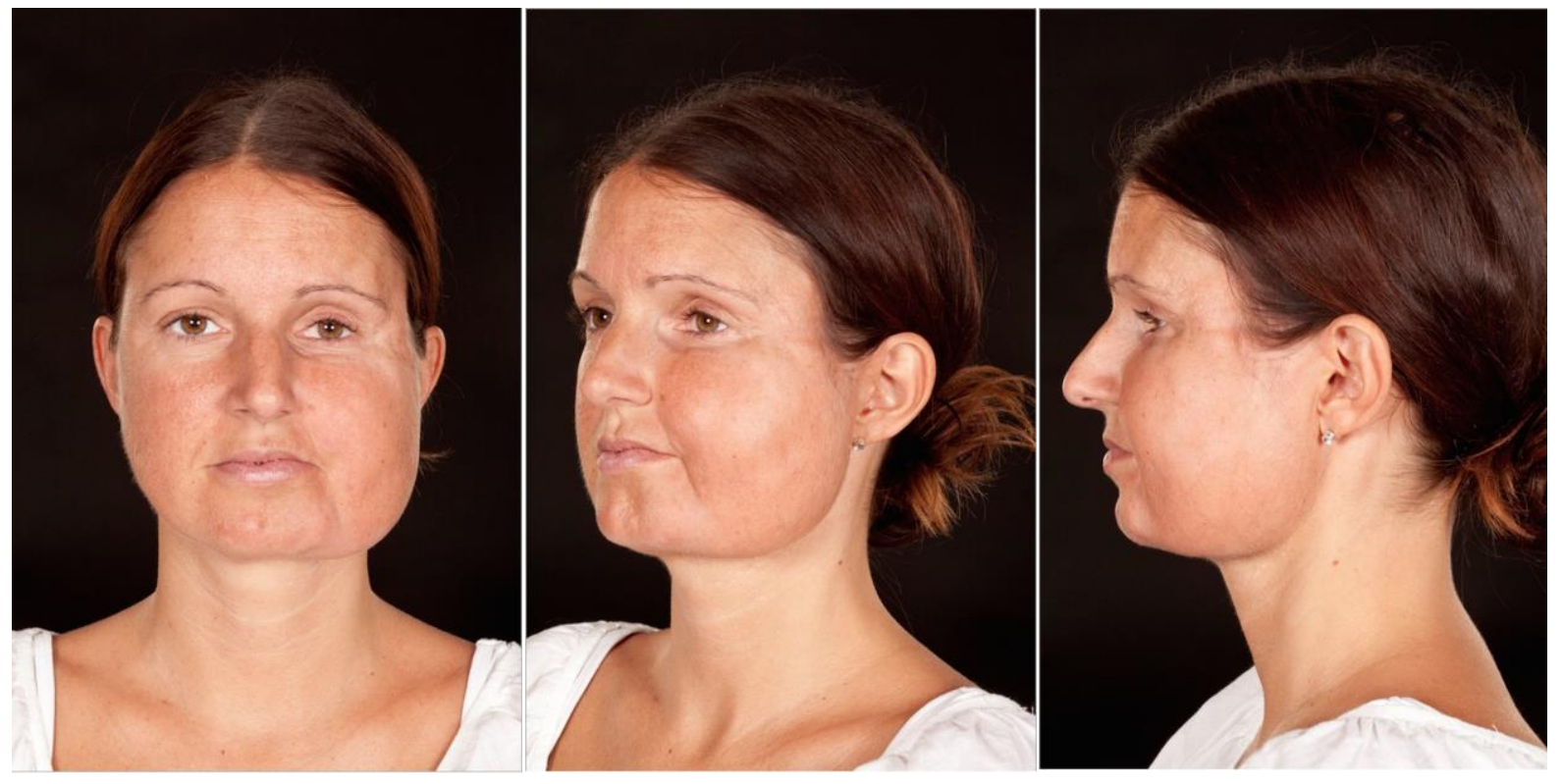

Figures 6a-6c: Female patient aged 38, 16 months post-operative $7^{\text {th }}$ fat transfer

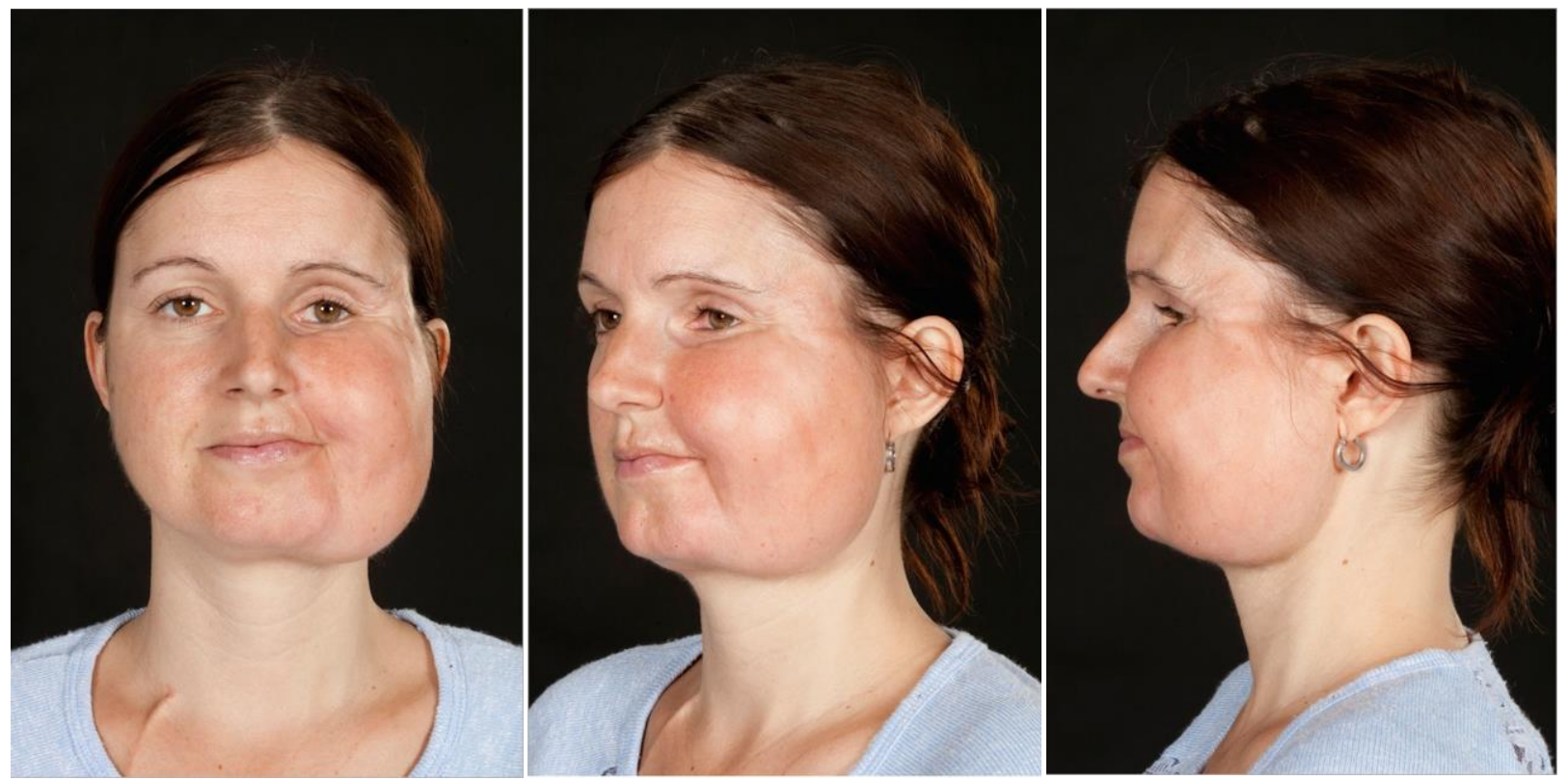


Figures 7a-7c: Female patient aged 40, 14 months postoperative $2^{\text {nd }}$ fat liposuction
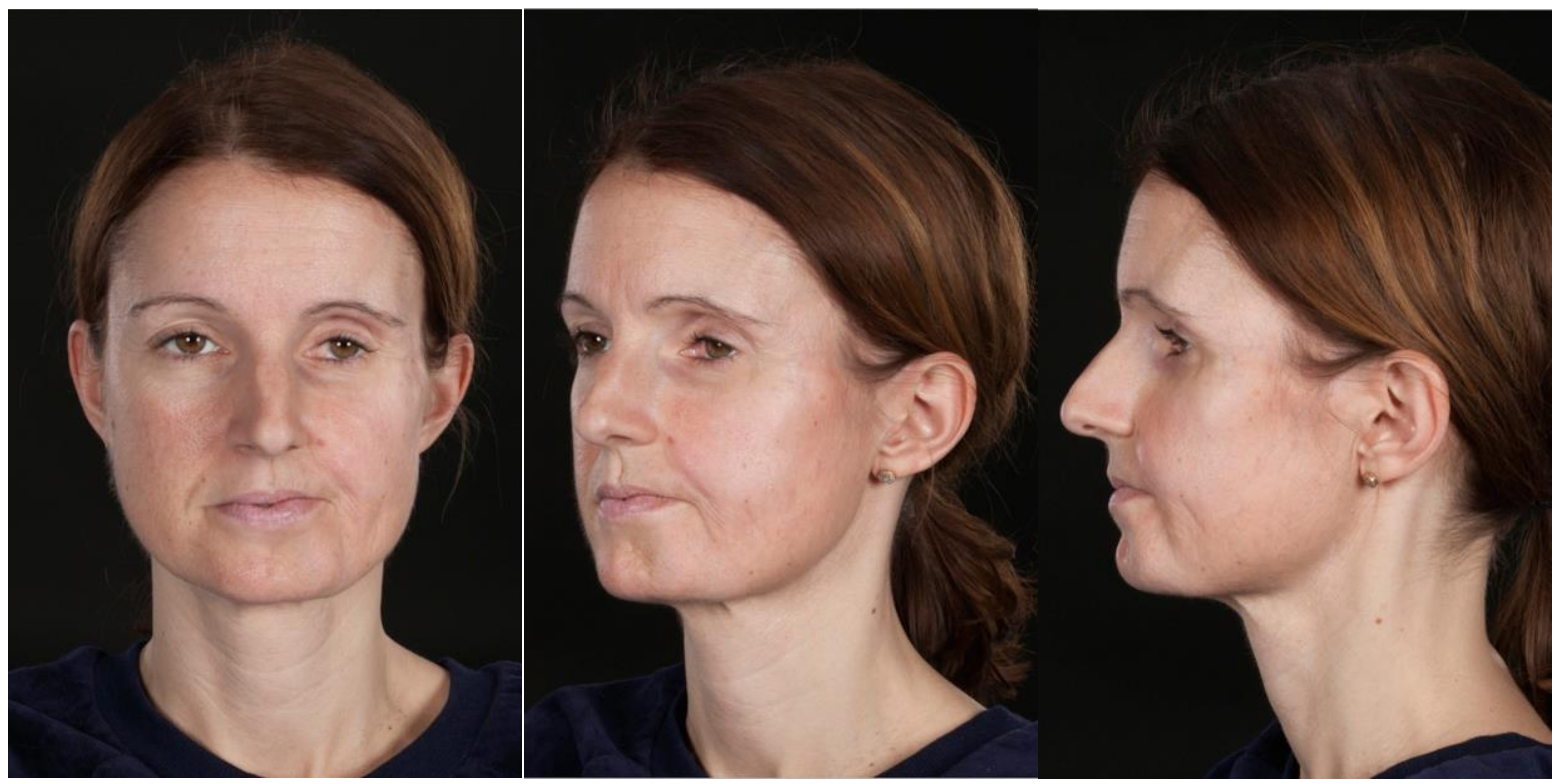

Tables

Table 1: Summary of fat transfer procedure details

\begin{tabular}{|l|l|l|l|l|}
\hline $\begin{array}{l}\text { Fat transfer } \\
\text { procedures }\end{array}$ & Date of Procedure & $\begin{array}{l}\text { Patient Age at Time } \\
\text { of Procedure (Years) }\end{array}$ & $\begin{array}{l}\text { Total Volume of Fat } \\
\text { Transferred (mL) }\end{array}$ & Recipient Site \\
\hline 1 & September 2009 & 32 & 43 & Infra-orbital area, nasolabial fold, mandibular area \\
\hline 2 & October 2010 & 34 & 45 & Hemiface, lips, chin \\
\hline 3 & October 2011 & 35 & 40 & Upper lip, cheek, chin, temple \\
\hline 4 & May 2012 & 35 & 43 & Hemiface \\
\hline 5 & October 2012 & 36 & 32.5 & Alar, chin \\
\hline 6 & June 2013 & 36 & 22 & Alar, chin, upper lip \\
\hline 7 & December 2013 & 37 & 11 & Retro-orbital area, upper eyelid and inner canthus, lower eyelid, nasolabial fold \\
\hline
\end{tabular}

Table 2: Summary of case studies reporting fat hypertrophy in literature to date

\begin{tabular}{|c|c|c|c|c|c|c|c|c|}
\hline Author & Age & Sex & Fat Donor Site & Fat Recipient Site & $\begin{array}{c}\text { Volume of Fat } \\
\text { Transfer }\end{array}$ & $\begin{array}{c}\text { Time for } \\
\text { Hypertrophy }\end{array}$ & Treatment & Cause \\
\hline Anis et al. (10) & 56 & M & Abdomen & Dural opening & Free fat graft & 2 years & - & Weight gain $8 \mathrm{~kg}$ \\
\hline Duhoux et al. (7) & 47 & $\mathrm{~F}$ & Gluteal/femoral & $\begin{array}{c}\text { Lower eyelid/upper } \\
\text { cheek }\end{array}$ & $10 \mathrm{~mL}$ & 1 year & $10 \mathrm{~mL}$ debulking & Weight gain $15 \mathrm{~kg}$ \\
\hline Hunstad et al. (5) & 9 & M & Abdomen & Hemiface & $13 \mathrm{~mL}$ & $<4$ years & Liposuction & $\begin{array}{l}\text { Significant growth spurt } \\
\text { and weight gain }\end{array}$ \\
\hline Latoni et al. (8) & 13 & $\mathrm{~F}$ & Abdomen /thigh & Lateral thigh & $75 \mathrm{~mL}$ & 15 months & $40 \mathrm{~mL}$ liposuction & Weight gain $4.5 \mathrm{~kg}$ \\
\hline Miller and Popp (6) & 19 & $F$ & Abdomen & Forehead & $20 \mathrm{~mL}$ & 10 years & Liposuction & Weight gain $6.8 \mathrm{~kg}$ \\
\hline Moullot et al. (11) & 30 & M & Abdomen/thigh & Penile shaft & $\begin{array}{c}370 \mathrm{~mL} \text { over } 3 \\
\text { sessions }\end{array}$ & 4 years & $250 \mathrm{~mL}$ liposuction & Weight gain $16 \mathrm{~kg}$ \\
\hline Roarke and Nguyen (12) & 73 & M & [DIEP flap] & [Pharyngeal Flap] & NA & - & - & $\begin{array}{c}\text { Improved nutritional } \\
\text { intake and resultant } \\
\text { weight gain }\end{array}$ \\
\hline Rousvoal et al. (13) & 42 & M & Abdomen & Malar/nasolabial & $15 \mathrm{~mL}$ & 3 months & $\begin{array}{l}>15 \mathrm{~mL} \text { liposuction } \\
\text { over } 2 \text { sessions due } \\
\text { to recurrence }\end{array}$ & $\begin{array}{l}\text { No change in weight or } \\
\text { antiretroviral regime }\end{array}$ \\
\hline Taupin et al. (4) & 13 & $\mathrm{~F}$ & Abdomen & Hemiface & $\begin{array}{c}92 \mathrm{~mL} \text { over } 5 \\
\text { sessions }\end{array}$ & 5 years & $\begin{array}{c}\text { Observation and } \\
\text { change in lifestyle }\end{array}$ & Weight gain $10 \mathrm{~kg}$ \\
\hline Teixeira et al. (9) & 8 & $\mathrm{M}$ & Abdomen & $\begin{array}{l}\text { Posterior pharyngeal } \\
\text { wall }\end{array}$ & $\begin{array}{c}12 \mathrm{~mL} \text { over } 2 \\
\text { sessions }\end{array}$ & 1 year & $\begin{array}{l}10 \mathrm{~mL} \text { debulking } \\
\text { then } 7 \mathrm{~mL} \text { debulking } \\
16 \text { months later }\end{array}$ & Weight gain $16.7 \mathrm{~kg}$ \\
\hline
\end{tabular}

